\title{
PENGARUH TOTAL QUALITY MANAGEMENT, BUDAYA ORGANISASI, GAYA KEPEMIMPINAN DAN KOMITMEN ORGANISASI TERHADAP KINERJA MANAJERIAL (Studi pada PT. Bank Rakyat Indonesia di Kota Jambi)
}

\author{
Alicia Pratiwi $^{1 *}$, Wirmie Eka Putra ${ }^{2)}$, Ratih Kusumastuti ${ }^{3)}$ \\ Program Studi Akuntansi, Universitas Jambi \\ Email: aliciapratiwi10@gmail.com
}

\begin{abstract}
Abstrak: Penelitian ini bertujuan untuk menganalisis pengaruh total quality management, budaya organisasi, gaya kepemimpinan, dan komitmen organisasi terhadap kinerja manajerial pada PT. Bank Rakyat Indonesia Tbk. di Kota Jambi. Penelitian ini menggunakan metode purposive sampling dengan jumlah sampel penelitian sebanyak 77 orang. Pengumpulan data dilakukan menggunakan kuesioner. Data primer yang didapat dari penelitian kemudian dianalisis dengan menggunakan alat uji regresi linier berganda menggunakan bantuan SPSS 22. Hasil penelitian ini menunjukkan bahwa total quality management, budaya organisasi, gaya kepemimpinan dan komitmen organisasi secara parsial berpengaruh terhadap kinerja manajerial. Dan hasil analisis secara bersama-sama menunjukkan bahwa total quality management, budaya organisasi, gaya kepemimpinan dan komitmen organisasi berpengaruh terhadap kinerja manajerial.
\end{abstract}

Kata Kunci: Total Quality Management; Budaya Organisasi; Gaya Kepemimpinan; Komitmen Organisasi; Kinerja Manajerial. 


\section{PENDAHULUAN}

Dunia perbankan merupakan salah satu sektor usaha yang mendukung berkembang dan berhasilnya perekonomian suatu negara juga harus mampu memberikan kepuasaan untuk nasabahnya, untuk itu kualitas juga diperlukan oleh perbankan agar tidak mengecewakan nasabah. Di zaman sekarang ini tidak bisa dipungkiri bahwa banyak faktor yang membuat kualitas suatu perusahaan semakin memburuk perbankan (Laiya dkk., 2018).

Meningkatkan kualitas perusahaan diperlukan kebijakan-kebijakan yang dibuat oleh manajer dalam mencapai tujuan perusahaan. Kinerja manajerial suatu perusahaan dianggap baik apabila tujuan perusahaan dapat terlampaui berdasarkan sasaran, standar dan kriteria yang telah ditetapkan sebelumnya, serta melakukan perbaikan secara terusmenerus. (Sulijaya dan Bangun, 2015).

Menghadapi tingkat persaingan yang kompetitif saat ini, perusahaan perlu menerapkan Total quality management (TQM) karena dengan menerapkan Total quality management (TQM) manajer memiliki kendali terhadap kualitas barang dan jasa yang diproduksi. Tingkat kepuasan pelanggan digunakan sebagai indikator pelayanan yang baik, serta dapat digunakan sebagai evaluasi manajer untuk memonitor kinerjanya dalam hal perbaikan kualitas produk dan pelayanan pelanggan guna meningkatkan penjualan maupun laba (Pamungkas, 2015).

Selain total quality management, budaya organisasi juga mempengaruhi kinerja manajerial. Budaya organisasi merupakan sistem penyebaran kepercayaan dan nilai-nilai yang berkembang dalam suatu organisasi dan mengarahkan perilaku anggotaanggotanya. Kesuksesan organisasi selain diukur dari karyawan dan keterkaitan budaya yang melekat padanya, juga dapat dilihat dari kinerja organisasi secara keseluruhan. Seorang manajer akan memengaruhi organisasi, baik buruknya organisasi berhubungan dengan kinerja manajerial (Triseptya dkk., 2017)

Gaya kepemimpinan juga mempengaruhi kinerja manajerial. Gaya kepemimpinan adalah suatu cara yang digunakan pemimpin dalam berinteraksi dengan bawahannya. Membangun kinerja manajerial yang efektif dan efisien dapat dilakukan dengan menciptakan suatu harmonisasi antara gaya kepemimpinan dan motivasi kerja yang dipimpinnya, sehingga membuat orang-orang yang terlibat merasa termotivasi dan bawahannya atau karyawannya menjadi lebih efektif dalam memberikan pelayanan yang memuaskan kepada nasabah atau masyarakat pelanggan (Ridwan dan Hamelinda, 2017)

Selain total quality management, budaya organisasi dan gaya kepemimpinan, komitmen organisasi juga termasuk salah satu yang mempengaruhi kinerja manajerial. Kinerja para manajer akan meningkat ketika para manajer mempunyai komitmen organisasi yang kuat . Komitmen organisasi yang kuat dalam diri individu akan menyebabkan inividu berusaha keras mencapai tujuan organisasi sesuai dengan tujuan dan kepentingan organisasi atas nama organisasi akan meningkatkan kinerja manajerial (Parwitasari dan Wirasedana, 2018).

PT. Bank Rakyat Indonesia (BRI) di Kota Jambi yang merupakan perusahaan jasa perbankan milik pemerintah yang melayani jasa perbankan, kredit maupun asuransi. Bank BRI merupakan bank tertua dan pertama di Indonesia yang didirikan pada 16 Desember 1895. PT. Bank Rakyat Indonesia (BRI) di Kota Jambi telah memperluas entitas unitnya, yang terdiri dari 1 kantor cabang utama, 2 kantor cabang pembantu, 1 kantor kas dan 13 unit.

PT. Bank Rakyat Indonesia (BRI) Tbk baru-baru ini mengalami penurunan dalam pencapaian kinerja perseroan tahun 2018 
dibandingkan tahun sebelumnya. Adapun data terkait penurunan kinerja perseroan PT. Bank Rakyat Indonesia sebagai berikut

Tabel 1. Gambaran kinerja keuangan BRI 2017 - 2018

\begin{tabular}{|c|c|c|c|}
\hline \multirow{2}{*}{ No. } & \multirow{2}{*}{ Uraian } & \multicolumn{2}{|c|}{ Tahun } \\
\hline & & 2017 & 2018 \\
\hline 1. & $\begin{array}{l}\text { Total } \\
\text { Aset }\end{array}$ & 1.126 .248 .442 & 1.119 .240 .112 \\
\hline 2. & $\begin{array}{l}\text { Total } \\
\text { Hutang }\end{array}$ & 958.900 .948 & 956.606 .454 \\
\hline 3. & Ekuitas & 167.347 .494 & 160.633 .658 \\
\hline 4. & $\begin{array}{l}\text { Laba } \\
\text { Bersih }\end{array}$ & 7.767 .117 & 6.228 .265 \\
\hline
\end{tabular}

Sumber : Laporan Keuangan BRI Tahun 2018

Dari tabel 1 diatas dapat dilihat bahwa adanya penurunan terhadap kredit yang disalurkan pada tahun 2018 sebesar Rp 956.606.454 yang turun dari tahun 2017 sebesar Rp 958.900.948 atau turun 0,24\% dan laba bersih pada tahun 2017 sebesar Rp 7.767.117 turun menjadi Rp 6.228.265 Sebagian besar keuntungan PT. Bank Rakyat Indonesia berasal dari pendapatan bunga yang diperoleh dari aktivitas penyaluran kredit yang berpengaruh terhadap laba perusahaan. Penurunan ini dikarenakan belum optimalnya penerapan total quality management, kurangnya budaya agresif dalam bekerja, terjadinya pergantian pimpinan dan rendahnya komitmen karyawan.

Penurunan kinerja perseroan PT. Bank Rakyat Indonesia memperlihatkan bahwa pelayanan terhadap nasabah bank BRI masih belum maksimal, terlihat dari banyaknya keluhan pelanggan terhadap kualitas pelayanan salah satunya banyak yang mengeluhkan atas seringnya terjadi penolakan terhadap pengajuan kredit dari nasabah. Bentuk data yang didapati pada saat observasi langsung berupa data keluhan pelanggan yang ada pada database pelanggan.

Disisi lain, banyaknya kredit macet dari nasabah yang terjadi pada PT. Bank atau turun $19,81 \%$ pada tahun 2018.

Rakyat Indonesia (BRI) di Kota Jambi membuat karyawan tidak berani mengambil resiko terutama dalam hal pemberian kredit. Tekanan yang didapatkan para karyawan ketika terjadinya kredit bermasalah di suatu perusahaan membuat karyawan tidak mau salah memutuskan dalam pemberian kredit. Tidak sebandingnya antara penghasilan dan tekanan yang didapatkan membuat karyawan melakukan tindakan yang merugikan perusahaan.

Dari sisi budaya, karyawan tampak tak agresif dalam bekerja ketika karyawan tidak mau mengambil resiko atas pemberian keputusan kredit kepada nasabah. Hal ini sangat berbanding terbalik dengan misi pada PT. Bank Rakyat Indonesia yaitu memberikan pelayanan prima dengan fokus pada pelanggan melalui sumber daya manusia yang profesional dan memiliki budaya berbasis kinerja (performance-driven culture) dengan menerapkan prinsip operational dan risk management excellence.

Mengenai keputusan pemberian kredit ini, juga dipengaruhi dari gaya kepemimpinan yang ada pada perusahaan tersebut tentang bagaimana para pemimpin mampu mempengaruhi bawahannya agar mau bekerja lebih optimal. Namun keadaan yang terjadi saat ini, PT. Bank Rakyat Indonesia di Kota Jambi sering mengalami pergantian pemimpin. Adapun data terkait perubahan pimpinan yang sering terjadi di PT. Bank Rakyat Indonesia (BRI) di Kota Jambi sebagai berikut :

Tabel 2. Data Pimpinan PT. Bank Rakyat Indonesia (BRI) di Kota Jambi Tahun 2017 - 2018

\begin{tabular}{|l|l|l|l|}
\hline $\begin{array}{l}\text { Nama } \\
\text { (Inisial) }\end{array}$ & Jabatan & $\begin{array}{l}\text { Kantor } \\
\text { / Unit }\end{array}$ & $\begin{array}{l}\text { Tanggal } \\
\text { Menjabat }\end{array}$ \\
\hline ZH & $\begin{array}{l}\text { Pemimpin } \\
\text { Cabang }\end{array}$ & $\begin{array}{l}\text { Kantor } \\
\text { Cabang } \\
\text { Utama }\end{array}$ & Juni 2017 \\
\hline MAR & $\begin{array}{l}\text { Pemimpin } \\
\text { Cabang }\end{array}$ & $\begin{array}{l}\text { Kantor } \\
\text { Cabang } \\
\text { Utama }\end{array}$ & $\begin{array}{l}\text { April } \\
\text { 2018 }\end{array}$ \\
\hline
\end{tabular}

302 JOURNAL OF APPLIED MANAGERIAL ACCOUNTING | Vol. 3, No. 2, 2019, 300-310| ISSN: 2548-9917 


\begin{tabular}{|l|l|l|l|}
\hline YWM & $\begin{array}{l}\text { Pemimpin } \\
\text { Cabang }\end{array}$ & $\begin{array}{l}\text { Kantor } \\
\text { Cabang } \\
\text { Utama }\end{array}$ & $\begin{array}{l}\text { Desember } \\
2018\end{array}$ \\
\hline
\end{tabular}

Sumber : Laporan Bank BRI 2018

Pada tabel 2 dapat dilihat bahwa sepanjang tahun 2017 -2018 PT. Bank Rakyat Indonesia di Kota Jambi mengalami pergantian pimpinan. Bedanya pimpinan tentunya mempengaruhi gaya kepemimpinan yang berbeda pula. Hal ini tentu membuat para pekerja akan sulit untuk menyesuaikan diri dengan gaya kepemimpinan yang berbeda-beda dan membuat para karyawan menjadi tidak konsisten dengan apa yang dikerjakannya dikarenakan perbedaan pola pikir dari pimpinan yang berbeda-beda.

Sejauh ini dapat dikatakan bahwa komitmen organisasi pada PT. Bank Rakyat Indonesia di Kota Jambi sangat rendah, terlihat dari penurunan kinerja perseroan pada PT. Bank Rakyat Indonesia di Kota Jambi dan juga terlihat dari para karyawan yang belum mampu bekerja secara optimal untuk berusaha keras sesuai keinginan organisasi dengan penerimaan nilai-nilai dan tujuan organisasi.

Berdasarkan uraian diatas maka peneliti tertarik untuk meneliti lebih lanjut apakah penerapan total quality managemenet, budaya organisasi, gaya kepemimpinan dan komitmen organisasi berpengaruh terhadap kinerja manajerial. Adapun judul yang diangkat oleh peneliti yaitu "Pengaruh Penerapan Total Quality Managemenet, Budaya Organisasi, Gaya Kepemimpinan Dan Komitmen Organisasi Terhadap Kinerja manajerial (Studi pada PT. Bank Rakyat Indonesia di Kota Jambi)

\section{KAJIAN LITERATUR}

\section{Total Quality Management}

Total quality management (TQM) merupakan suatu sistem yang dikembangkan menjadi sebuah pendekatan dalam menjalakan kegiatan operasional usaha guna memaksimalkan daya saing organisasi melalui perbaikan terus menerus atas produk, jasa, tenaga kerja, proses, dan lingkungannya berdasarkan konsep kualitas, teamwork produktivitas, pengertian, dan kepuasan pelanggan (Tjiptono, 1998). Ada 4 prinsip utama yang dikembangkan oleh (Pamungkas, 2015) seperti halnya : fokus pada pelanggan, respek terhadap setiap orang, manajemen berdasarkan fakta dan perbaikan berkesinambungan.

1. Fokus pada pelanggan

2. Respek terhadap setiap orang

3. Manajemen berdasarkan fakta

4. Perbaikan berkesinambungan

\section{Budaya Organisasi}

Menurut (Robbins \& Judge, 2008) budaya organisasi merupakan kesepakatan perilaku anggota dalam organisasi yang selalu berusaha menciptakan efisiensi, kreatif, bebas dari kesalahan dan berfokus pada hasil, sehingga indikator budaya organisasi adalah

a. Inovasi memperhitungkan resiko

b. Memberi perhatian pada setiap masalah secara detil.

c. Berorientasi terhadap hasil yang akan dicapai.

d. Berorientasi kepada semua kepentingan anggota.

e. Agresif dalam bekerja.

f. Mempertahankan dan menjaga stabilitas kerja.

\section{Gaya Kepemimpinan}

Menurut (Robbins \& Judge, 2008) menyatakan bahwa gaya kepemimpinan adalah kemampuan individu untuk emmpengaruhi, memotivasi dan membuat orang lain mampu memberikan kontribusinya demi efektivitas dan keberhasilan organisasi.

\section{Komitmen Organisasi}

Komitmen merupakan penerimaan yang kuat dari individu terhadap tujuan 
dan nilai-nilai organisasi, dan individu berupaya serta berkarya dan memiliki hasrat yang kuat untuk tetap bertahan di organisasi tersebut. Komitmen juga merupakan integritas disiplin dalam diri seseorang dan konsisten dengan apa yang sudah disepakati dalam kehidupannya baik dalam lingkungan sosial, organisasi dan lingkungan keluarga.

\section{Kinerja Manjerial}

Kinerja manajerial merupakan kinerja para individu anggota organisasi dalam kegiatan-kegiatan manajerial antara lain perencanaan, investigasi, koordinasi, evaluasi, supervisi, pengaturaan staf, negoisasi, dan representasi. Kinerja manajerial sangat dibutuhkan dalam organisasi guna memberikan keberhasilan bagi perusahaan yang dipimpinnya karena semua keputusan pada dasarnya merupakan pemikiran dari seorang manajer. (Pamungkas, 2015). Kinerja personel seorang manajer meliputi :

1. Merencanakan

2. Mengorganisasikan

3. Memimpin

4. Mengendalikan

5. Mengevaluasi

\section{METODE PENELITIAN}

Penelitian ini termasuk dalam penelitian kuantitatif sebab itu pendekatan yang dilakukan dalam penelitian ini adalah pendekatan deskriptif kuantitatif. Data kuantitatif adalah data yang diukur dalam suatu skala numerik (angka) yang dibedakan menjadi data interval dan data rasio. data kualitatif umumnya dikuantitatifkan agar dapat diproses lebih lanjut (Kumentas, 2013).

Jenis data yang digunakan dalam penelitian ini adalah data primer. (Ridwan dan Yogi, 2018) menyatakan bahwa data primer dapat didefinisikan sebagai data yang dikumpulkan dari sumber-sumber asli untuk tujuan tertentu. Sumber data penelitian ini berupa hasil kuesioner yang telah diisi oleh responden, yang terdiri dari hasil jawaban responden yang telah dikumpulkan dengan mengirimkan kuesioner kepada top management level, middle menagement level, dan lower management level pada PT. Bank Rakyat Indonesia (BRI) di Kota Jambi.

\section{Populasi dan Sampel Penelitian}

Populasi dalam penelitian ini adalah seluruh karyawan PT. Bank Rakyat Indonesia (BRI) di Kota Jambi. Dan sampel penelitian ini adalah Top management, middle management dan lower management pada PT. Bank Rakyat Indonesia (BRI) di Kota Jambi. Dipilih karena merupakan individu yang menjalankan kegiatan manajerial yang memiliki kendali dalam hal evaluasi kinerja.

Berdasarkan data kualifikasi di atas, maka terdapat 77 responden yang dapat dijadikan sampel dalam penelitian ini seperti yang ditampilkan pada tabel 3 berikut ini:

Tabel 3. Sampel Penelitian

\begin{tabular}{|l|l|l|}
\hline No & Keterangan & $\begin{array}{l}\text { Jumlah } \\
\text { Sampel }\end{array}$ \\
\hline 1. & $\begin{array}{l}\text { Kantor Cabang } \\
\text { Jambi Abunjani }\end{array}$ & 19 \\
\hline 2. & $\begin{array}{l}\text { KCP } \\
\text { Sipin }\end{array}$ & 7 \\
\hline 3. & KCP Jelutung & 2 \\
\hline 4. & KK Poltabes Jambi & 3 \\
\hline 5. & Unit Fatahilah & 3 \\
\hline 6. & Unit Talang Banjar & 3 \\
\hline 7. & Unit Angso Duo & 3 \\
\hline 8. & Unit Thehok & 3 \\
\hline 9. & Unit Simp. IV Sipin & 3 \\
\hline 10. & Unit Pasar Jambi & 3 \\
\hline 11. & Unit Simp. Kawat & 3 \\
\hline 12. & Unit Sultan Thaha & 3 \\
\hline 13. & Unit Kasang Jaya & 3 \\
\hline 14. & Unit Simp. Rimbo & 3 \\
\hline 15. & Unit Mayang & 3 \\
\hline 16. & Unit Kebun Handil & 3 \\
\hline 17. & Unit Talang & 3 \\
\hline Total & 77 \\
\hline
\end{tabular}




\section{Metode Analisis}

Analisis data yang dilakukan pada penelitian ini menggunakan bantuan program komputer yaitu SPSS (Statistical Package For Social Science) versi 22.0. Alat analisis yang digunakan dalam penelitian ini adalah analisis regresi linier berganda.

\section{Uji Kualitas \\ Uji Validitas}

Uji validitas yang digunakan untuk mengukur sah atau valid tidaknya suatu kuesioner. Kuesioner dikatakan valid jika pertanyaan pada kuesioner mampu untuk mengungkapkan sesuatu yang akan diukur oleh kuesioner tersebut. Mengukur tingkat validitas dapat dilakukan dengan melakukan korelasi antara skor butir pertanyaan dengan total score konstruk (Sunyoto, 2013).

\section{Uji Reliabilitas}

Uji reliabilitas adalah alat untuk mengukur suatu kuesioner yang merupakan indikator dari variabel atau konstruk. Butir pertanyaan dikatakan reliabel apabila jawaban jawaban seseorang terhadap pertanyaan adalah konsisten. Uji ini dapat dilihat dari nilai Cronbach Alpha. Suatu konstruk dikatakan reliabel jika memberikan nilai Cronbach Alpha $>0,60$ (Sunyoto, 2013).

\section{Uji Asumsi Klasik}

\section{Uji Normalitas}

Uji normalitas data digunakan untuk menguji data variabel bebas $(X)$ dan data variabel terikat $(\mathrm{Y})$ pada persamaan regresi yang dihasilkan berdistribusi normal atau tidak normal. Persamaan regresi dikatakan baik jika mempunyai data variabel bebas dan data variabel terikat berdistribusi mendekati normal atau normal sama sekali (Sunyoto, 2013).

\section{Uji Multikolinearitas}

Uji multikolinieritas dimaksudkan untuk membuktikan apakah terdapat hubungan linier antar variabel independen (multikolinieritas). Model regresi yang baik seharusnya tidak terjadi korelasi diantara variabel bebas. Multikolinieritas dapat dilihat tolerance value atau variance inflaction factor (VIF) diatas 10 maka terjadi multikolinieritas (Sunyoto, 2013).

\section{Uji Heteroskedastisitas}

Uji heteroskedastisitas bertujuan untuk menguji apakah dalam model regresi terjadi ketidaksamaan variance dari residual satu pengamatan ke pengamatan yang lain. Jika variance dari residual satu pengamatan ke pengamatan yang lain tetap, maka disebut homoskedastisitas dan jika berbeda disebut heterokedastisitas. Persamaan regresi yang baik jika tidak terjadi heteroskedastisitas. Untuk mendeteksi ada atau tidaknya heterokedastisitas dapat dilakukan dengan melihat grafik Plot antara nilai prediksi variabel terikat (dependen) dengan residual (Sunyoto, 2013).

\section{Analisis Regresi Linier Berganda}

Metode analisis data yang digunakan dalam penelitian ini adalah analisis regresi linier berganda dengan bantuan komputer melalui program SPSS 22.0 for windows. Regresi linier berganda digunakan untuk menguji hipotesis 1-5. Persamaan yang digunakan sebagai berikut:

$\mathrm{Y}=\alpha+\beta 1 \mathrm{X} 1+\beta 2 \mathrm{X} 2+\beta 3 \mathrm{X} 3+\beta 4 \mathrm{X} 4+\mathrm{e}$

Keterangan:

$\mathrm{Y}=$ Kinerja Manajerial

X1 = Total Quality Management

$\mathrm{X} 2$ = Budaya Organisasi

X3 = Gaya Kepemimpinan

X4 = Komitmen Pimpinan

$\alpha=$ Konstanta

$\beta=$ Koefisien Regresi

e $=$ error 


\section{Pengujian Hipotesis}

Hipotesis penelitian diuji dengan menggunakan model analisis regresi berganda. Pengujian hipotesis digunakan untuk menguji ada atau tidaknya pengaruh variabel independen terhadap variabel dependen, dalam pengujian hipotesis ini digunakan bantuan paket program SPSS 22 for Windows. Pengujian hipotesis dilakukan dengan uji $\mathrm{F}$ dan uji $\mathrm{T}$.

\section{Uji F}

Untuk menjawab rumusan masalah pertama, maka digunakan uji F. Pengujian hipotesis secara simultan (keseluruhan) dengan uji $\mathrm{F}$ menunjukkan apakah variabel bebas secara keseluruhan atau bersamasama mempunyai pengaruh terhadap variabel tak bebas (Ghozali, 2011). Adapun langkah-langkah pengujian hipotesis tersebut adalah :

a. Menentukan $F_{\text {hitung }}$ berdasarkan hasil output analisis regresi

b. Tingkat signifikansi $(\alpha) 0,05$ atau 5\% untuk menguji apakah hipotesis yang diajukan dalam penelitian ini diterima atau ditolak

c. Kriteria pengujian

Jika $F_{\text {hitung }}>F_{\text {tabel }}$ atau Sig. $<0,05$, berarti H0 ditolak

Jika $F_{\text {hitung }}<F_{\text {tabel }}$ atau Sig. $>0,05$, berarti H0 diterima

\section{Uji T}

Untuk menjawab rumusan masalah kedua, ketiga, keempat, dan kelima maka digunakan uji statistik t. Pengujian parameter individu (Uji t) dimaksudkan untuk melihat apakah variabel secara individu mempunyai pengaruh terhadap variabel tak bebas dengan asumsi variabel bebas lainnya konstan (Ghozali, 2011). Dari perhitungan tersebut maka selanjutnya membandingkan antara nilai $t_{\text {hitung }}$ dengan $t_{\text {tabel }}$ pada tingkat keyakinan 95\% $(\alpha=0,05)$ dengan kriteria keputusan : Jika - ttabel $\leq t_{\text {hitung }} \leq t_{\text {tabel }}$ atau Sig. $>0,05$ : $\mathrm{H} 0$ diterima
Jika $-t_{\text {hitung }}<t_{\text {tabel }}$ atau $t_{\text {hitung }}>t_{\text {tabel }}$ atau Sig. $<0,05: \mathrm{H} \alpha$ diterima

\section{Koefisien Determinasi $\left(\mathbf{R}^{2}\right)$}

Untuk menjawab rumusan masalah keenam koefisien determinasi $\left(\mathrm{R}^{2}\right)$ dilakukan untuk melihat seberapa jauh kemampuan model dalam menerangkan variasi dependen. Adjusted $\mathrm{R}^{2}$ berkisar antara nol sampai $1\left(0 \leq\right.$ adjusted $\left.\mathrm{R}^{2} \leq 1\right)$. Hal ini berarti bila digunakan adjusted $\mathrm{R}^{2}$ $=0$ menunjukkan tidak adanya pengaruh antara variabel independen terhadap variabel dependen, bila adjusted $\mathrm{R}^{2}$ semakin besar mendekati 1 , menunjukkan semakin kuatnya pengaruh variabel independen terhadap variabel dependen dan bila adjusted $\mathrm{R}^{2}$ semakin kecil mendekati 0, maka dapat dikatakan semakin kecilnya pengaruh variabel independen terhadap variabel dependen (Ghozali, 2011).

\section{HASIL DAN PEMBAHASAN}

Distribusi kusioner dan tingkat pengembalian tercantum dalam tabel berikut :

Tabel 4. Jumlah Sampel dan Tingkat Pengembalian

\begin{tabular}{|l|l|}
\hline Penyebaran Kusioner & Jumlah \\
\hline Kusioner yang disebar & 77 \\
\hline Kusioner yang kembali & 66 \\
\hline Kusioner yang tidak kembali tidak & 11 \\
\hline $\begin{array}{l}\text { Kusioner yang } \\
\text { lengkap/rusak }\end{array}$ & 0 \\
\hline Tingkat Pengembalian Kusioner & $85,71 \%$ \\
\hline
\end{tabular}

Sumber : Data Olahan

\section{Hasil Uji Kualitas}

Berdasarkan hasil ini dapat dinyatakan bahwa semua pertanyaan dari setiap variabel dalam penelitian ini dinyatakan valid karena tiap item pertanyaan memiliki tingkat signifikansi $<0,05$. Uji reliabilitas dalam penelitian ini dapat dikatakan bahwa setiap butir pertanyaan reliable karena setiap variabel dalam penelitian ini memiliki cronbach's alpha >0,60. 


\section{Hasil Uji Asumsi Klasik}

Pengujian normalitas dalam penelitian ini menghasilkan grafik dengan data menyebar disekitar garis diagonal dan mengiuti garis diagonal, maka dapat dikatakan hasil dalam penelitian ini terdistribusi normal. Untuk uji multikolinieritas dalam penelitian ini menunjukkan nilai tolerance diatas 0,1 dan VIF kurang dari 10 dan dapat dikatakan bahwa tidak ada multikolinieritas antar variabel independen dalam model regresi . Pengujian heteroskedastisitas dalam penelitian ini titik-titik menyebar secara acak dan baik maupun dbawah angka 0 pada sumbu Y. Hal ini dapat disimpulkan bahwa tidak terjadi heteroskedastisitas pada model regresi layak dipakai .

\section{Hasil Pengujian Hipotesis}

\section{Uji T}

\section{Tabel 5. Koefisien Regresi}

\begin{tabular}{|l|r|r|r|r|r|}
\hline & \multicolumn{2}{|c|}{$\begin{array}{l}\text { Unstandard } \\
\text { ized } \\
\text { Coefficient } \\
\text { s }\end{array}$} & $\begin{array}{r}\text { Standa } \\
\text { rdizCo } \\
\text { efficie } \\
\text { n }\end{array}$ & & \\
\cline { 2 - 4 } Model & B & $\begin{array}{c}\text { Std. } \\
\text { Error }\end{array}$ & Beta & t & Sig. \\
\hline $\begin{array}{l}\text { 1 (Consta } \\
\text { nt })\end{array}$ &, 758 & 2,569 & &, 295 &, 769 \\
$\begin{array}{l}\text { TQM } \\
\text { (X1) }\end{array}$ &, 218 &, 102 &, 224 & 2,136 &, 037 \\
$\begin{array}{l}\text { BO } \\
\text { (X2) }\end{array}$ &, 179 &, 072 &, 336 & 2,486 &, 016 \\
$\begin{array}{l}\text { GK } \\
\text { (X3) }\end{array}$ &, 233 &, 106 &, 211 & 2,202 &, 031 \\
$\begin{array}{l}\text { KO } \\
\text { (X4) }\end{array}$ &, 240 &, 110 &, 212 & 2,184 &, 033 \\
\hline
\end{tabular}

Dependent Variable: Kinerja Manajerial $(\mathrm{Y})_{\mathrm{a}}$

Hasil uji $\mathrm{t}$ menunjukkan bahwa nilai konstan yaitu $\alpha=0,758$, sedangkan koefisien variabel total quality management sebesar 0,218, koefisien variabel budaya organisasi yaitu sebesar 0,179 sedangkan koefisien variabel gaya kepemimpinan yaitu sebesar 0,233 dan koefisien variabel komitmen organisasi yaitu sebesar 0,240. Dari koefisien regresi di atas dibentuk persamaan regresi sebagai berikut:

$Y=0,758+0,218 X_{1}+0,179 X_{2}+0,233 X_{3}+0,240$

Persamaan regresi di atas menjelaskan halhal sebagai berikut:

a. Koefisien variabel total quality management $\left(\mathrm{X}_{1}\right)$ yaitu sebesar 0,218 , hal ini memperlihatkan bahwa setiap $1 \%$ peningkatan total quality management akan meningkatkan kinerja manajerial sebesar $0,218 \%$.

b. Koefisien variabel budaya organisasi $\left(X_{2}\right)$ sebesar 0,179 , hal ini berarti bahwa setiap peningkatan budaya organisasi sebesar 1\%, akan meningkatkan kinerja manajerial sebesar 0,179\%.

c. Koefisien variabel gaya kepemimpinan $\left(\mathrm{X}_{3}\right)$ sebesar 0,233, hal ini berarti bahwa setiap peningkatan gaya kepemimpinan sebesar 1\%, akan meningkatkan kinerja manajerial sebesar 0,233\%.

d. Koefisien variabel komitmen organisasi $\left(\mathrm{X}_{4}\right)$ sebesar 0,240 , hal ini berarti bahwa setiap peningkatan komitmen organisasi sebesar $1 \%$, akan meningkatkan kinerja manajerial sebesar $0,240 \%$.

Uji F

\section{Tabel 6. Hasil Uji F}

ANOVA $^{\text {a }}$

\begin{tabular}{|c|c|c|c|c|c|}
\hline Model & $\begin{array}{l}\text { Sum of } \\
\text { Squares }\end{array}$ & $\mathrm{df}$ & $\begin{array}{l}\text { Mean } \\
\text { Square }\end{array}$ & $\mathrm{F}$ & Sig. \\
\hline 1 Regressio & 483,367 & 4 & 120,842 & 50,229 &, $000^{\mathrm{b}}$ \\
\hline Residual & 146,754 & 61 & 2,406 & & \\
\hline Total & 630,121 & 65 & & & \\
\hline
\end{tabular}

Tabel 6. diatas memperlihatkan tingkat signifikansi $<0,05$ maka $\mathrm{H}_{0}$ ditolak dan 
menerima $\mathrm{H}_{\mathrm{a}}$. Ini menunjukkan bahwa hipotesis alternatif yang diajukan diterima, semua variabel independen yaitu total quality management, budaya organisasi, gaya kepemimpinan dan komitmen organisasi secara bersama-sama memiliki pengaruh yang signifikan terhadap kinerja manajerial.

\section{Koefisien Determinasi}

Tabel 7. Koefisien Korelasi dan Koefisien Determinasi Model Summary ${ }^{b}$

\begin{tabular}{|l|l|l|l|l|}
\hline Model & $R$ & $\begin{array}{l}\text { R } \\
\text { Square }\end{array}$ & $\begin{array}{l}\text { Adjusted } \\
\text { Square }\end{array}$ & $\begin{array}{r}\text { R Std. Error of the } \\
\text { Estimate }\end{array}$ \\
\hline 1 &, $876^{2}$ &, 767 &, 752 & 1,551 \\
\hline
\end{tabular}

a. Predictors: (Constant), Komitmen Organisasi (X4), Gaya Kepemimpinan (X3), TQM (X1), Budaya Organisasi (X2)

b. Dependent Variable: Kinerja Manajerial (Y)

Tabel 7 diatas memperlihatkan bahwa besarnya koefisien determinasi (Adjusted $R$ Square) yaitu sebesar 0,752. Hal ini berarti bahwa total quality management, budaya organisasi, gaya kepemimpinan dan komitmen organisasi memiliki pengaruh sebesar 0,752 yang masuk dalam kategori sangat kuat

\section{Pembahasan}

Hasil penelitian ini menunjukkan bahwa total quality management memiliki pengaruh yang signifikan terhadap kinerja manajerial. Hal ini dapat dilihat dari hasil pengujian hipotesis dengan tingkat signifikansi $<0,05$ yang berarti hipotesis yang diajukan dalam penelitian ini diterima yaitu bahwa total quality management merupakan salah satu prediktor yang baik dalam meningkatkan kinerja manajerial.Hal ini berarti bahwa semakin tinggi penerapan total quality management maka kinerja manajerial akan semakin baik. Dengan dilakukannya penerapan total quality management yang optimal akan mendorong para karyawan untuk sehingga akan meningkatkan kinerjanya dalam mencapai tujuan organisasi.

Hasil penelitian ini memperlihatkan adanya pengaruh budaya organisasi yang positif dan signifikan terhadap kinerja manajerial yang dibuktikan dengan tingkat signifikansi $<0,05$. Dengan demikian hipotesis kedua yang diajukan dalam penelitian ini diterima sehingga budaya organisasi berpengaruh terhadap kinerja manajerial. Semakin tinggi budaya organisasi yang diterapkan, maka kinerja manajerial akan semakin meningkat dimana setiap satu persen peningkatan budaya organisasi akan meningkatkan kinerja manajerial sebesar $0,179 \%$. Hal ini berarti bahwa semakin baik budaya organisasi perusahaan akan meningkatkan kinerja manajerial disuatu perusahaan Hasil penelitian ini memperlihatkan bahwa gaya kepemimpinan berpengaruh terhadap kinerja manajerial yang dibuktikan dengan tingkat signifikansi $<0,05$. Dengan demikian hipotesis ketiga yang diajukan dalam penelitian ini diterima sehingga semakin baik gaya kepemimpinan akan meningkatkan kinerja manajerial. Gaya kepemimpinan yang baik mampu mempengaruhi bawahannya guna mencapai tujuan perusahaan.

Hasil penelitian ini memperlihatkan bahwa komitmen organisasi berpengaruh signifikan terhadap kinerja manajerial yang dibuktikan dengan tingkat signifikansi $<0,05$. Dengan demikian hipotesis keempat yang diajukan diterima sehingga semakin tinggi komitmen organisasi akan meningkatkan kualitas kinerja manajerial. Setiap satu persen peningkatan komitmen organisasi mampu meningkatkan kinerja manajerial sebesar $0,240 \%$. Komitmen yang tinggi menjadikan manajer lebih mementingkan organisasi dari pada pada kepentingan pribadi dan berusaha menjadikan organisasi menjadi lebih baik. Maka dari itu komitmen dalam organisasi berpengaruh terhadap kinerja yang dihasilkan dari sebuah organisasi

Hasil penelitian ini menunjukkan bahwa total quality management, budaya organisasi, gaya kepemimpinan dan komitmen organisasi berpenngaruh 
signifikan terhadap kinerja manajerial. Hal ini dapat dilihat dari hasil pengujian hipotesis dengan tingkat signifikansi pada uji $\mathrm{f}<0,05$. Dengan demikian bahwa hipotesis kelima yang diajukan dalam penelitian ini diterima sehingga total quality management, budaya organisasi, gaya kepemimpinan dan komitmen organisasi secara bersama-sama mampu meningkatkan kinerja manajerial.

Besarnya pengaruh total quality management, budaya organisasi, gaya kepemimpinan dan komitmen organisasi secara bersama-sama terhadap kinerja manajerial yaitu sebesar 0,752 pengaruh tqm, budaya organisasi, gaya kepemimpinan dan komitmen oganisasi terhadap kinerja manajerial sangat kuat.

\section{KESIMPULAN DAN SARAN}

\section{Simpulan}

Berdasarkan hasil analisis data dan pembahasan hasil penelitian dapat disimpulkan bahwa total quality management, budaya organisasi, gaya kepemimpinan dan komitmen organisasi secara parsial berpengaruh terhadap kinerja manajerial. Dan hasil pengujian menunjukkan bahwa total quality management, budaya organisasi, gaya kepemimpinan dan komitmen organisasi secara bersama-sama memiliki pengaruh terhadap kinerja manajerial

\section{Saran}

Berdasarkan hasil penelitian dan kesimpulan yang telah peneliti uraikan, maka saran yang dapat direkomendasikan adalah:

1. Penelitian ini menggunakan variabel total quality management, budaya organisasi, gaya kepemimpinan, dan komitmen organisasi dalam mempengaruhi kinerja manajerial. Disarankan dalam penelitian selanjutnya peneliti dapat mengembangkan variabel-variabel lain seperti, GCG, karakteristik perusahaan, serta kinerja perusahaan dengan dimensi yang lebih komprehensif.

2. Untuk mendapatkan hasil yang lebih optimal dan untuk menghidari bias maka diusahakan peneliti selanjutnya menggunakan metode interview selain menggunakan kuesioner agar mendapatkan data yang lebih akurat.

3. Memperluas wilayah pengambilan sampel dan melakukan penambahan jumlah agar dapat mengeneralisasikan hasil penelitian dengan menggunakan responden yang berbeda.

\section{DAFTAR PUSTAKA}

Ghozali, I. (2011). Aplikasi Analisi Multivariate dengan menggunakan SPSS. Gramedia.

Kumentas, C. N. (2013). Pengaruh TQM, Sistem Pengukuran Kinerja Dan Penghargaan Terhadap Kinerja Manajerial PT. Pos Indonesia. EMBA, 1(3).

Laiya, R. A. R., Jan, A. H., \& Pondaag, J. (2018). Pengaruh Total Quality Management (TQM) Terhadap Kinerja Manajerial Pada PT. Bank Mandiri (Persero) Tbk Area Manado, 6(4), 2658-2667.

Pamungkas, K. T. (2015). Pengaruh Total Quality Management Terhadap Kinerja Manajerial (Studi Empiris Di Perusahaan Daerah Pasar Surya). AKRUAL, 6(2), 175-193.

Parwitasari, A. . S. I. D., \& Wirasedana, I. W. P. (2018). Pengaruh Penerapan Total Quality Management, Komitmen Organisasi Pada Kinerja Manajerial Dengan Reward Sebagai Variabel Moderasi. E-Jurnal Akuntansi Universitas Udayana, 25(3), 2072-2097. 
Ridwan, M., \& Hamelinda, F. (2017). Pengaruh Gaya Kepemimpian, Motivasi Kerja dan Komitmen Organisasi Terhadap Kinerja Manajerial (Survey Pada Kantor Cabang Pembantu Bank Di Kota Sungai Penuh). Jurnal Manajemen Terapan Dan Keuangan, 6(3), 147225.

Ridwan, M., \& Yogi, S. (2018). Pengaruh Penerapan Total Quality Management, Sistem Pengukuran Kinerja, Gaya Kepemimpinan, dan Komitmen Pimpinan Terhadap Kinerja Manajerial (Studi Empiris Pada Perusahaan Jasa Titipan Kilat Di Kota Jambi). Jurnal Manajemen Terapan Dan Keuangan, 7(03), 263273.
Robbins, S. P., \& Judge, T. A. (2008). Perilaku organisasi. Edisi Kedua belas. Jakarta: Salemba Empat.

Sulijaya, F., \& Bangun, N. (2015). Pengaruh Total Quality Management, Motivasi Dan Komitmen Organisasi Terhadap Kinerja Manajerial (Pada PT Sekar Bumi, Tbk). Jurnal Akuntansi, 19(3), 433-448.

Sunyoto, D. (2013). Metodologi Penelitian Akuntansi (Cetakan Kesatu). PT. Refika Aditama.

Triseptya, G. N., Pagulung, G., \& Indrijawati, A. (2017). Pengaruh Partisipasi Anggaran, Komitmen Dan Budaya Organisasi Terhadap Kinerja Manajerial Dengan Gaya Kepemimpinan Sebagai Moderasi. Journal of Management \& Business, 1(1), 34-45. 